International Journal of English Literature and Social Sciences
Vol-6, Issue-1; Jan-Feb, 2021
Journal Home Page Available: $\underline{\text { https://ijeab.com/ }}$
Journal DOI: $10.22161 /$ ijels

\title{
Teaching Strategies of Physical Education Instructors of Kalinga State University
}

\author{
Jemille P. Garcia
}

Kalinga State University, Philippines

Received: 19 Nov 2020; Received in revised form: 21 Jan 2021; Accepted: 14 Feb 2021; Available online: 23 Feb 2021

(C)2021 The Author(s). Published by Infogain Publication. This is an open access article under the CC BY license

(https://creativecommons.org/licenses/by/4.0/).

\begin{abstract}
In terms of their gender, age, length of physical education teaching experience, number of subjects/teaching load, specialization, and number of training, seminars, or workshops related to the topic of physical education, this study focused on the teaching performance of the physical education instructors at Kaling State University.

A mixed-method with a descriptive sample and qualitative design was used by the investigator. The key data collection method used in the analysis was the Teacher Assessment Tool. To self-assess their results, it was administered to the educators. The PE Instructors have an awareness that their teaching output is generally true of them in terms of teaching abilities, teaching materials, and teaching strategies mentioned in the survey questionnaires addition, the level of teaching efficiency between the PE Major Instructors and the Non-PE Major Instructors who teach Physical Education does not vary significantly.

Therefore, with the outcome of the data examined, the researcher suggests that the feedback of students about their PE instructors be done to decide whether the expectations of the instructors about their teaching results and teaching methods are the same as the feedback of the students about them.

Keywords-Teaching Strategies, PE Major Instructors, Physical Education.
\end{abstract}

\section{INTRODUCTION}

\section{A. BACKGROUND OF THE STUDY:}

The research was used to indicate the importance of meeting teaching expectations and to provide high-quality teaching. Teachers are the backbone of the educational method, as per Seferoglu 2005; Cleofynne 2004.

Teachers are responsible for delivering information, talents, and practical experience to students inside and outside the classroom. Teachers should therefore have a high-quality level of teaching skills that can be described as "the positive combination of the individual's knowledge, ability and willingness to deal effectively and responsibly with changing situations" (Weinert, 2001).

Physical Education is one of the general education and training support groups that can help students build and strengthen leadership skills, selfconfidence, actions in the classroom, love, and appreciation for themselves and the community (Camlico 2008).

Physical education classes are still considered by students to be an enjoyable and usually optimistic experience (Gullu, Guclu and Arslan 2009, Sisko and Demirhan 2002, Tannehi and Zakrajsek 1993), but there have been waves of growth and changes due to the influence of a contemporary political, social and cultural event that culminated in comprehensive educational reform.

However, if teachers in physical education have a high degree of instructional skills, they can effectively provide training, control the classroom, and contribute to the growth of students.

This research study was adapted from $\mathrm{Mr}$. Ricardo A. Obeda's 2007-2008 study entitled "Physical Education in Selected Secondary Schools in the Balicuatro Region of Northern Samar." This parallel study was 
motivated by his work because the researchers are inspired to study in a university setting in order to have a deeper understanding of the value of physical education instructors' success for their competitiveness, not only locally, but also globally.

\section{B. CONCEPTUAL FRAMEWORK:}

- INPUT

1. PE (Physical

Education) Instructors Profile

2. Survey questionnaire

3. Focus group discussion

4. Informal interview with the PE Instructors

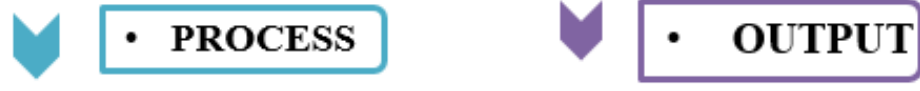

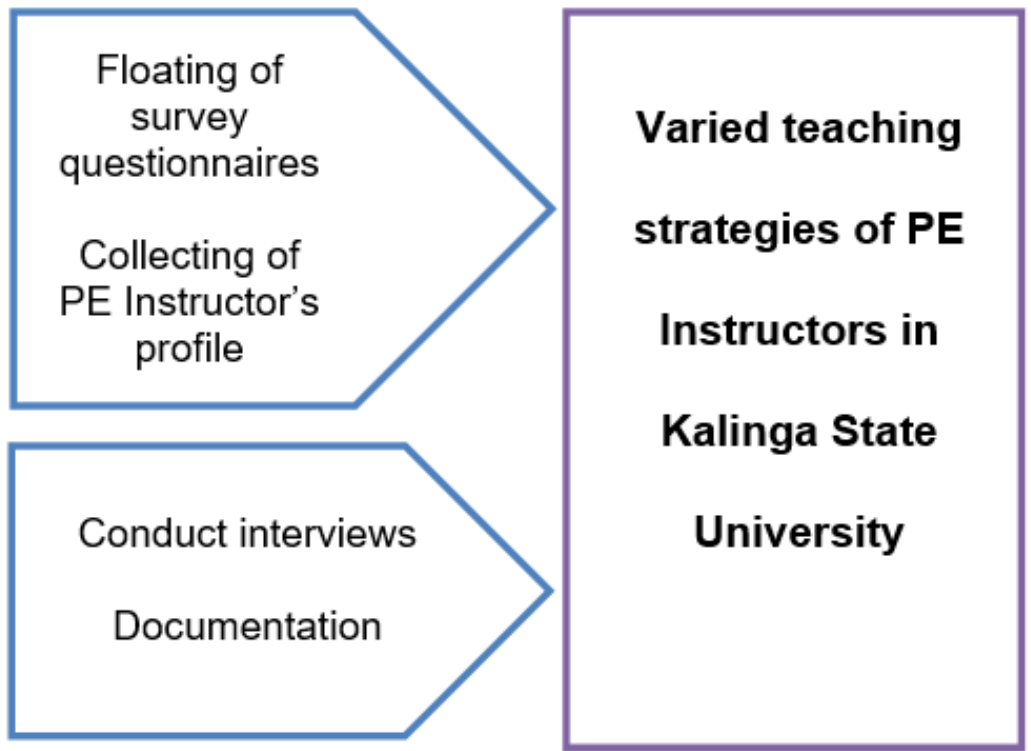

\section{OBJECTIVE OF THE STUDY:}

The study aimed to determine the teaching performance of Physical Education Instructors atKalinga State University. Specifically, it sought answers to the following questions:

1. What is the profile of the PE instructors in terms of the following?
1.1 Gender
1.2 Age
1.3 Length of Physical Education teaching experience
1.4 Number of subjects/teaching load
1.5 Specialization
1.6 Number of training, seminars or workshops related to Physical Education subject
1.7 Length of Physical Education teaching experience

2. What are the teaching strategies used by the Physical Education instructors in teaching Physical Education subject?

3. What is the level of performance of Physical Education in teaching the subject?

4. Is there a significant difference in the level of teaching performance between the Physical Education Major Instructors and the Non-Physical Education Major Instructors in teaching Physical Education? 4.a There is no significant difference in the level of teaching performance between the Physical Education Major Instructors and the NonPhysical Education Instructors in teaching Physical Education.

4.b There is a significant relationship in the level of teaching performance between the Physical Education Major Instructors and the NonPhysical Education Instructors in teaching Physical Education.

\section{SCOPE AND DELIMITATION OF THE STUDY:}

The study focused on the Physical Education Instructors teaching at Kalinga State University, both Physical Education Major and non-Physical Education Major. As of this semester, there are 16 Physical Education Instructors assigned to teach Physical Education in the different departments of the university.

\section{METHODOLOGY}

This part of the study presents the locale of the study, research design, the respondents/sample/ 
participants of the study, data gathering, data analysis, and the statistical tool used in analyzing of data.

A. The locale of the Study:

The study was held at the three campuses of Kalinga State University namely: Bulanao Main Campus, Dagupan Campus, and Rizal Campus.

\section{B. Research Design:}

The researcher used a mixed-method with a descriptive survey and qualitative design. The study aimed to collect information about the prevailing situations, the trends developed, and to determine if there was a difference in the teaching performance between the Physical Education Major instructors and the NonPhysical Education Major instructors who are teaching Physical Education.

\section{Respondents / Research The study participants:}

Among the participants of this report, the researcher used purposeful sampling of nine Physical Education Major Instructors and two Non-Physical Education Majors who have been teaching physical education at Kalinga State University for the last 2 years, specifically at Dagupan Campus, Rizal Campus, and Bulanao Main Campus.

\section{Instrumentation:}

A questionnaire was used as a data collection tool that the researcher directly administered with an informal interview conducted with the respondents to obtain data that could validate the findings of the researcher. The review consists of two parts. Part I included the respondent's teaching profile and Part II included questions about the teaching success of teachers in physical education.

\section{Data Gathering:}

In conducting the questionnaire, the researcher sought the approval of the relevant authorities. The questionnaire was administered and retrieved directly by the researcher upon acceptance, clarifying things that were vague to the respondents. Help for this research was sought from the deans of various colleges to speed up the collection of data.The questionnaire used a 5-point Likert Scale where 1 was the lowest and 5 as the highest. Answers to each of the questions in the questionnaire were tallied, tabulated, analyzed, and interpreted. Shown in the table below is the scale and description of the 5point Likert Scale used in answering the questionnaire.

\begin{tabular}{|l|l|l|}
\hline Scale & Range & Descriptive Value \\
\hline 5 & $4.50-5.00$ & Always/ almost true \\
\hline 4 & $3.50-4.49$ & Usually true of me \\
\hline 3 & $2.50-3.49$ & Somewhat true of me \\
\hline 2 & $1.50-2.49$ & Usually not true of \\
\hline 1 & $1.00-1.49$ & Never/ almost never \\
\hline
\end{tabular}

The scale ranged from $\mathbf{1}$ to $\mathbf{5}$ whose descriptive values range from Never/ almost never true of me to Always/ almost true of me where Never/ almost never true of me is given a scale of $\mathbf{1}$, Usually not true of me is given a scale of $\mathbf{2}$, Somewhat true of me is given a scale of $\mathbf{3}$, Usually true of me is given a scale of $\mathbf{4}$ and Always/ almost true of me is given a scale of 5

\section{Data Analysis:}

To analyze and interpret the information obtained from the responses, there were two formulas used. For answering questions 1 to 3 , a simple "mean" or "average" is used, where all the products of the values given in the questionnaire and the frequency of occurrence are summarized and then divided by the total number of answers. This was used for each item to measure the average answer. The "t-test" for independent samples was used with a null hypothesis to answer question number 4 . $\mathrm{T}$

The following table shows the outcome of the collected data from the study:

Table 1 indicates the number of respondents according to the profile of teachers.

\begin{tabular}{|c|c|c|c|c|c|c|c|c|c|c|c|c|c|c|c|c|c|}
\hline \multirow{2}{*}{ 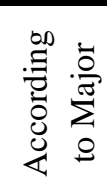 } & \multicolumn{2}{|c|}{ Gender } & \multicolumn{3}{|c|}{ Age } & \multicolumn{3}{|c|}{$\begin{array}{l}\text { Length of } \\
\text { service }\end{array}$} & \multicolumn{3}{|c|}{$\begin{array}{c}\text { No. of Teaching } \\
\text { Hours }\end{array}$} & \multicolumn{3}{|c|}{ No. of Training } & \multicolumn{3}{|c|}{ Degree Earned } \\
\hline & M & $\mathrm{F}$ & $21-30$ & $31-40$ & $41-50$ & $0-3$ & $4-6$ & 7 plus & $15-18$ & $19-22$ & $23-26$ & $0-5$ & $6-10$ & $\begin{array}{c}11 \\
\text { plus }\end{array}$ & BSED & $\begin{array}{l}\text { MAED } \\
\text { /MST }\end{array}$ & Ph. D \\
\hline$\frac{\overline{0}}{\sum_{\frac{\pi}{2}}^{\frac{N}{2}}}$ & 1 & 7 & 1 & 2 & 5 & 0 & 3 & 5 & 3 & 1 & 4 & 3 & 0 & 5 & 1 & 2 & 5 \\
\hline 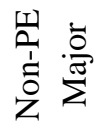 & 3 & 0 & 0 & 3 & 0 & 2 & 1 & 0 & 1 & 2 & 0 & 2 & 1 & 0 & 3 & 0 & 0 \\
\hline
\end{tabular}


The table shows that among the $\mathbf{1 1}$ respondents $\mathbf{8}$ are PE Majors. Among the PE Majors $\mathbf{1}$ belongs to age ranging from $21-30 ; 2$ belong to age ranging from 31-40 and 5 belong to age ranging from 41-50.

There are 3 who served in the public for 4 to 6 years; $\mathbf{5}$ served the public for 7 years and more.

There are $\mathbf{3}$ who have 15 to 18 teaching hours; $\mathbf{1}$ has 19 to 22 teaching hours and $\mathbf{4}$ have 23 to 26 teaching hours.

There are $\mathbf{3}$ who have none to 5 pieces of training and $\mathbf{5}$ who have 11 and more training about PE.

There is $\mathbf{1}$ who is a BSED graduate, $\mathbf{2}$ who are MAED/MST Graduate, and $\mathbf{5}$ who are Ph. D. Graduate.
Among the 11 respondents, there were 3 who were male Non-PE Majors too. All of the $\mathbf{3}$ belong to age ranging from 31 to 40 . There are 2 of them had been teaching for about 3 years and $\mathbf{1}$ has been teaching for 4 to 6 years. There is $\mathbf{1}$ who has 15 to 18 teaching hours and $\mathbf{2}$ of them teach from 19 to 22 hours. There are $\mathbf{2}$ of them who have none to 5 relevant pieces of training and $\mathbf{1}$ has about 6 to 10 relevant pieces of training. All the $\mathbf{3}$ are Bachelor's Degree Holders.

Table 2 shows the result gathered about the teaching strategies of the Physical Education Instructors:

Table 2: The MEAN teaching strategies of the PE Instructors

\begin{tabular}{|c|c|}
\hline Strategies in teaching Physical Education & Mean \\
\hline 1. I help students to have confidence in themselves & 4.44 \\
\hline 2. I teach students how to change their negative reactions into positive ones. & 4.48 \\
\hline 3. I encourage students to interact positively among themselves & 4.60 \\
\hline 4. I train students to refer to their success or failure to own capabilities & 4.59 \\
\hline 5. I apply for group work in the class to serve the desired objectives & 4.53 \\
\hline 6. I provide students with a chance to apply new knowledge in a new real-life situation & 4.22 \\
\hline 7. I usually make criteria in judging the students' performance & 4.01 \\
\hline 8. I use the direct presentation to provide students with information & 3.74 \\
\hline 9. I give students enough time to question and investigate the desired objective. & 4.06 \\
\hline 10. I begin the teaching-learning situation by presenting a problem to my students & 4.07 \\
\hline 11. I end the teaching-learning situation with a clarifying diagram suitable for students & 4.12 \\
\hline 12. I help my students identify their learning methods & 4.18 \\
\hline 13. I provide students with a chance to apply new knowledge in a new real-life situation & 4.32 \\
\hline 14. I help my students to have confidence in themselves & 4.52 \\
\hline $\begin{array}{l}\text { 15. I make advantage of the contract procedures with my students to achieve the teaching-learning } \\
\text { tasks. }\end{array}$ & 4.29 \\
\hline OVERALL MEAN for TEACHING STRATEGIES & 4.27 \\
\hline
\end{tabular}

Table 2 shows that the instructors' perception about their teaching strategies has a Mean of 4.27 which means that the 15 strategies in teaching Physical Education described under strategies in teaching Physical Education are usually true of them.

Table 3: The Overall Mean teaching performance of the PE Instructors of KSU

\begin{tabular}{|l|c|}
\hline Teaching Skills & $\begin{array}{l}\text { Overall } \\
\text { Result }\end{array}$ \\
\hline 1. I always present and explain the objectives of the lesson clearly at the start of the lesson. & 4.35 \\
\hline 2. I am organized in presenting subject matters by systematically following the course outline. & 4.06 \\
\hline 3. I always update myself with present trends, relevant to the subject matter. & 4.23 \\
\hline 4. I use various strategies, teaching aids/ devices, and techniques in presenting the lessons. & 4.18 \\
\hline
\end{tabular}


5. I work to create lessons so my students will enjoy learning and become independent thinkers.

\section{Instructional Materials}

1. I use chalk and blackboard in explaining the lessons

2. I use PowerPoint presentation as my visual aids

3. I usually demonstrate Physical activities for the student's understanding.

\section{Strategies in teaching Physical Education}

1. I help students to have confidence in themselves

2. I teach students how to change their negative reactions into positive ones.

3. I encourage students to interact positively among themselves

4. I train students to refer to their success or failure to own capabilities

5. I apply for group work in the class to serve the desired objectives

6. I provide students with a chance to apply new knowledge in a new real-life situation

7. I usually make criteria in judging the students' performance

8. I use a direct presentation to provide students with information

9. I give students enough time to question and investigate the desired objective.

10. I begin the teaching-learning situation by presenting a problem to my students

11. I end the teaching-learning situation with a clarifying diagram suitable for students

12. I help my students identify their learning methods

13. I provide students with a chance to apply new knowledge in a new real-life situation

14. I help my students to have confidence in themselves

15. I make advantage of the contract procedures with my students to achieve the teaching-learning tasks.

\section{OVERALL MEAN FOR TEACHING PERFORMANCE}

Table 3 shows that the instructors' perception about their teaching performance has a Mean of 4.19 which means that, it is usually true of them that they perform in terms of teaching skills, instructional materials, and strategies in teaching Physical Education as described under in the survey questionnaire.

Table 4.The Mean teaching performance of the PE Major and the Non-PE Major

\begin{tabular}{|c|c|c|}
\hline Teaching Skills & $\begin{array}{l}\text { PE } \\
\text { Major }\end{array}$ & \begin{tabular}{|l|} 
Non \\
PE \\
Major \\
\end{tabular} \\
\hline 1. I always present and explain the objectives of the lesson clearly at the start of the lesson. & 4.55 & 4.5 \\
\hline 2. I am organized in presenting subject matters by systematically following the course outline. & 4.44 & 3.5 \\
\hline 3. I always update myself with present trends, relevant to the subject matter. & 4.44 & 4.5 \\
\hline 4. I use various strategies, teaching aids/ devices, and techniques in presenting the lessons. & 4.33 & 4.5 \\
\hline 5. I work to create lessons so my students will enjoy learning and become independent thinkers. & 3.88 & 5 \\
\hline \multicolumn{3}{|l|}{ Instructional Materials } \\
\hline 1. I use chalk and blackboard in explaining the lessons & 3.55 & 3 \\
\hline 2. I use PowerPoint presentation as my visual aids & 3.88 & 4 \\
\hline 3. I usually demonstrate Physical activities for the student's understanding. & 4.55 & 5 \\
\hline
\end{tabular}




\begin{tabular}{|c|c|c|}
\hline Strategies in teaching Physical Education & & \\
\hline 1. I help students to have confidence in themselves & 4.55 & 5 \\
\hline 2. I teach students how to change their negative reactions into positive ones. & 4.77 & 4.5 \\
\hline 3. I encourage students to interact positively among themselves & 4.77 & 5 \\
\hline 4. I train students to refer to their success or failure to own capabilities & 4.77 & 5 \\
\hline 5. I apply for group work in the class to serve the desired objectives & 4.66 & 5 \\
\hline 6. I provide students with a chance to apply new knowledge in a new real-life situation & 4.44 & 4.5 \\
\hline 7. I usually make criteria in judging the students' performance & 4.33 & 4 \\
\hline 8. I use a direct presentation to provide students with information & 4 & 4 \\
\hline 9. I give students enough time to question and investigate the desired objective. & 4.44 & 4 \\
\hline 10. I begin the teaching-learning situation by presenting a problem to my students & 4.11 & 5 \\
\hline 11. I end the teaching-learning situation with a clarifying diagram suitable for students & 4.33 & 4 \\
\hline 12. I help my students identify their learning methods & 4.22 & 5 \\
\hline 13. I provide students with a chance to apply new knowledge in a new real-life situation & 4.44 & 5 \\
\hline 14. I help my students to have confidence in themselves & 4.66 & 5 \\
\hline $\begin{array}{l}\text { 15. I make advantage of the contract procedures with my students to achieve the teaching-learning } \\
\text { tasks. }\end{array}$ & 4.77 & 3.5 \\
\hline MEAN OF TEACHING PERFORMANCE & 4.38 & 4.45 \\
\hline
\end{tabular}

Table 4 shows that there were two groups of instructors having their perception of their teaching performance. The first group was the PE Instructors who are major in $\mathrm{PE}$ and the second group was the $\mathrm{PE}$ Instructors who are not major in PE. The first group of instructors has a perception about their teaching performance with a Mean of $\mathbf{4 . 3 8}$ which means that it is usually true of them that they perform in terms of teaching skills, instructional materials, and strategies in teaching Physical Education as described under in the survey questionnaire. The second group of instructors has a perception about their teaching performance with a Mean of $\mathbf{4 . 4 5}$ which means that it is usually true of them that they perform in terms of teaching skills, instructional materials, and strategies in teaching Physical Education as described under in the survey questionnaire.

Table 5: Making a Decision with the Null Hypothesis of the Study

\begin{tabular}{|c|c|c|c|c|c|}
\hline $\begin{array}{l}\text { According to } \\
\text { Major }\end{array}$ & $\begin{array}{l}\text { Mean Teaching } \\
\text { Performance }\end{array}$ & $\begin{array}{l}\text { Mean } \\
\text { Difference }\end{array}$ & $\begin{array}{l}\text { t-computed } \\
\text { value }\end{array}$ & $\begin{array}{l}\text { t-tabular } \\
\text { value }\end{array}$ & t-computed value is \\
\hline PE Major & 4.38 & \multirow{2}{*}{0.07} & \multirow{2}{*}{0.0089} & \multirow{2}{*}{2.262} & value at .05 level of \\
\hline Non-PE Major & 4.45 & & & & significance \\
\hline
\end{tabular}

Since the t-computed value of $\mathbf{. 0 0 8 9}$ is less than the t-tabular value of $\mathbf{2 . 2 6 2}$ at a .05 level of significance with 9 degrees of freedom, the null hypothesis is confirmed which means that there is no significant difference in the level of teaching performance between the PE Major Instructors and Non-PE Major Instructors in teaching Physical Education.

\section{CONCLUSION}

The researchers were able to get it done at the following conclusions based on the data presented:

1. In the different departments of the 3 campuses of Kalinga State University, there are 11 PE professors, of which 3 are non-PE majors and 8 are PE majors.

2. The PE instructors have an understanding that their teaching methods outlined in the survey questionnaire are generally true of them. 
3. The PE Instructors have an understanding that their teaching output is true in general in terms of teaching abilities, learning aids, and learning styles mentioned in the survey questionnaire.

4. The level of teacher effectiveness between the PE Major Instructors and the Non-PE Major Instructors who teach Physical Education is not substantially different.

\section{RECOMMENDATION}

With the result of the data analyzed, the researcher, therefore, recommends that students' feedback about their $\mathrm{PE}$ instructors be done to determine if the instructors' perceptions about their teaching performance and teaching strategies are the same as that of the students' feedback about them

\section{REVIEW OF LITERATURE}

Teaching is as much an art as research, according to Brain (2001). It permits an immense degree of independence and honors the individual teacher's imagination. Masston\&Astworth (1986) note that teaching is an art of a teacher in which the subject matter is placed before the students in a meaningful way based on information and experience. This indicates that the active instructor is engaged in modifying and updating tasks set according to the needs of students in physical education. Strategies for teaching vary. Some teaching techniques enable learners to advance at their own pace, while others cultivate the ability to overcome situations previously not experienced by combining old rules and values into new higher-order ones in pupils (Harrison \& Blackmore, 1992).

Teaching strategies used by some teachers can increase student accountability for learning and feedback, while others allow learners to advance without the teacher's immediate presence through a sequence of learning activities. The teacher's ability to bring subject matters before the students in an imaginative way can also affect the success of the students in physical education. Student success can be credited to the teacher's application of different physical education teaching techniques. There is little interest paid by teachers in different schools to the use of several teaching techniques. Also, Mawer (1997) notes that for anyone teaching style on the continuum, there is no better approach. It is against this backdrop that the researchers realized that teaching methods used by primary and public school teachers needed to be studied.

Physical Education teaching requires a repertoire of effective teaching methods to allow the principles and skills of physical education to be learned. It seems that the successful use of different techniques by most physical education teachers is adversely influenced by several factors.
The study aimed to examine the teaching strategies used in Gokwe north primary schools in the midlands province of Zimbabwe by physical education teachers and also to evaluate the factors influencing the effectiveness of these strategies. This research adopted a qualitative methodology that directed the generation of relevant data using the case study design.For data collection, a total of twenty-four participants were conveniently sampled and these included three school heads, six physical educators, and two students in fifteen forms. To gain the perspectives of the three groups of participants, three focus group discussions were used. Study results showed that teachers of physical education apply many teaching techniques. These included seminars, individualized teaching, assignment teaching, cooperative learning, problemsolving, collaborative teaching, peer, station, simulation, and active teaching. Some were used more frequently than others among the mentioned teaching strategies.The efficacy of these teaching methods was found to be negative because a host of factors such as negative teacher attitudes, lack of subject examinations, lack of time, lack of sufficient equipment and facilities adversely affect them. The research suggested that the Ministry make the subject examinable to enhance the attitude of teachers and heads. School heads should have the necessary facilities and equipment to allow a variety of strategies to be used and also to strengthen the efficacy of the strategies (Singobile G.et. al) 2009This study aims to report on a survey performed out to analyze the efforts of two teachers in physical education (PE) to learn and incorporate the student-centered pedagogy of the Teaching Games for Understanding (TGfU) approach, using the Action Research (AR) framework as a research methodology. The research was motivated by two in-service PE teachers from a primary school in Athens, Greece, each responsible for a different grade three and four student class. Over a period of two months, the two teachers used an AR cyclical process of planning, applying, researching, and focusing on the TGfU approach to bring change to their professional practice and their students' learning. To generate details, reflective articles, survey questions, paper reviews, and non-participant observations were being used.For data analysis, inductive analysis and a constant comparative approach (Denzin\& Lincoln 1994) were used and three key themes emerged: teaching PE with TGfU, learning inside TGfU for students, and acting and researching on TGfU for teachers. It was found from the results that $\mathrm{AR}$, although initially a difficult undertaking, is an effective structure for enhancing the ability of PE teachers to design non-hierarchical lesson activities dedicated to the comprehension and development of students, such as those suggested by the TGfU approach. 


\section{CONCLUSION}

The researchers were able to get it done at the following conclusions based on the data presented:

1. In the different departments of the 3 campuses of Kalinga State University, there are $11 \mathrm{PE}$ professors, of which 3 are non-PE majors and 8 are PE majors.

2. The PE instructors have an understanding that their teaching methods outlined in the survey questionnaire are generally true of them.

3. The PE Instructors have an understanding that their teaching output is true in general in terms of teaching abilities, learning aids, and learning styles mentioned in the survey questionnaire.

4. The level of teacher effectiveness between the PE Major Instructors and the Non-PE Major Instructors who teach Physical Education is not substantially different.

\section{RECOMMENDATION}

With the result of the data analyzed, the researcher, therefore, recommends that students' feedback about their PE instructors be done to determine if the instructors' perceptions about their teaching performance and teaching strategies are the same as that of the students' feedback about them.

\section{REFEREECES}

[1] AMANDA MOONEY T. (2013). Back to the future" building mentoring capacity in physical education teacher education student : An "assessment for learning" approach. 16.11Deakin University.

[2] DANIA ASPASIA, NAKI CHRYSOULA, STASINOS PANAGIOTIS, LYKESAS GEORGIOS. 2017. Physical Education Teachers' Action Research on Teaching Games for Understanding. School of Physical Education and Sport Science, National and Kapodistrian University of Athens, GreeceDepartment of Primary Education, National and Kapodistrian University of Athens, Greece Department of Physical Education and Sport Science, Aristotle University of Thessaloniki, Greece .

[3] DAVID HORTIGÜELA ALCALÁ, ALEJANDRO JOSE SALICETTI FONSECA, JESSENIA HERNANDEZELIZONDO (2018), Original motivational contrast in physical education depending on caloric expenditure contrast motivational and education and function. Revista Internacional de Medicina y Ciencias de la Actividad Fisica y del Deporte.

[4] JOHN HAMILTON C. (2016). Physical Education Teaching Strategies \& Styles. Christopher Newport University.

[5] KJERSTI MORDAL MOEN\&KEN GREEN,. (2012), Physical education teacher education in Norway: The perceptions of student teachers,. Hedmark University College, University of Chester.
[6] MICHAEL SPITTLE, D, (2015),. Content of curriculum in physical education teacher education: expectations of undergraduate physical education students. $\underline{\text { Victoria }}$ University Melbourne.

[7] SEDA SARACALOĞLU1, S. RANA VAROL2, MURAT OZSAKER1. 2012. Teaching Strategies Preferred By the Teachers Of Physical Education And Sports: Ege University, School of Physical Education and Sport, İzmir, 1Adnan Menderes University, School of Physical Education and Sport, Aydin (TURKEY)

[8] SUSAN CAPEL P. (2007),. Value orientations of student physical education teachers learning to teach on schoolbased initial teacher education courses in England,. European Physical Education Review.

[9] TAN, W. K., MACDONALD, D., \& ROSSI, T. (2009). Educational action research in Singapore: to prove or improve? Asia Pacific Journal of Education.

[10] USHER, W., EDWARDS, A., \& DE MEYRICK, B. (2015). Utilizing educational theoretical models to support effective physical education Pedagogy . Cogent Education. 